\title{
UNCOMMON DEMOCRACIES
}


This book is based on a conference sponsored by the Joint Committees on Japanese Studies and Western Europe of the American Council of Learned Societies and the Social Science Research Council, and the Japan Society for the Promotion of Science. Support for the activities of the Joint Committees was provided by the Ford Foundation and the National Endowment for the Humanities. 


\section{Uncommon Democracies}

\section{The One-Party Dominant Regimes}

Edited by

T. J. PEMPEL

CORNELL UNIVERSITY PRESS

I T H A C A A N D L O N D O N 


\section{Copyright (C) 1990 by Cornell University}

All rights reserved. Except for brief quotations in a review, this book, or parts thereof, must not be reproduced in any form without permission in writing from the publisher. For information, address Cornell University Press, 124 Roberts Place, Ithaca, New York 14850.

First published 1990 by Cornell University Press.

International Standard Book Number 0-8014-2367-8 (cloth)

International Standard Book Number 0-8014-9696-9 (paper)

Library of Congress Catalog Card Number 89-22111

Librarians: Library of Congress cataloging information appears on the last page of the book.

(2) The paper used in this publication meets the minimum requirements of the American National Standard for Permanence of Paper for Printed Library Materials Z39.48-1984. 